Article

\title{
Immediate Effects of Prescribed Fire on Sub-Surface Water Quality in a Managed Yellow Pine Forest
}

\author{
Kipling Klimas ${ }^{1, * \mathbb{D}}$, Patrick Hiesl ${ }^{1}{ }^{\mathbb{D}}$, Donald Hagan ${ }^{1}$ and Dara Park ${ }^{2}$ \\ 1 Department of Forestry and Environmental Conservation, Clemson University, Clemson, SC 29634, USA; \\ Phies1@clemson.edu (P.H.); dhagan@clemson.edu (D.H.) \\ 2 Department of Plant and Environmental Sciences, Clemson University, Clemson, SC 29634, USA; \\ Dpark@clemson.edu \\ * Correspondence: kklimas@clemson.edu
}

Received: 14 April 2020; Accepted: 16 May 2020; Published: 19 May 2020

\begin{abstract}
Although prescribed fire is a forest management tool annually applied to nearly one million hectares across the southeastern United States, little is known about how prescribed fire influences soil water quality in the region. Sub-surface pools of nitrogen $(\mathrm{N})$ and phosphorous $(\mathrm{P})$ are important indicators of ecosystem response to disturbance and are likely modified, at least temporarily, by fire. We undertook a five-month study to examine sub-surface nutrient concentrations and $\mathrm{pH}$ in a managed yellow pine (Pinus sp.) forest before and after a low-severity dormant season prescribed fire in the Southern Blue Ridge Mountains of South Carolina. Between February and July 2019, soil solution was collected weekly from a $30 \mathrm{~cm}$ porous cup suction lysimeters and analyzed for ammonium $\left(\mathrm{NH}_{4}{ }^{+}\right)$, nitrate $\left(\mathrm{NO}_{3}{ }^{-}\right)$, and orthophosphate $\left(\mathrm{PO}_{4}{ }^{3-}\right)$, as well as $\mathrm{pH}$. We compared the five-month mean and maximum nutrient concentrations and $\mathrm{pH}$ to quantify the immediate effects of prescribed fire. The prescribed fire caused significant $\mathrm{pH}$ buffering towards neutrality in burned transects relative to the control. There was no change in soil solution $\mathrm{NO}_{3}{ }^{-}$. The prescribed fire caused a significant increase in maximum $\mathrm{NH}_{4}{ }^{+}(18.0 \mathrm{mg} / \mathrm{L})$ and $\mathrm{PO}_{4}{ }^{3-}(6.6 \mathrm{mg} / \mathrm{L})$ concentrations. Post-fire $\mathrm{NH}_{4}{ }^{+}$concentrations reached a maximum of $18.0 \mathrm{mg} / \mathrm{L}$ before declining three weeks post-fire. $\mathrm{PO}_{4}{ }^{3-}$ concentrations in burned stands reached a maximum of $6.6 \mathrm{mg} / \mathrm{L}$ and remained elevated for four weeks post-fire. Nutrient leaching was minimal due to complexion to soil cations and ground water uptake from regenerating vegetation at the onset of the growing season. The $\mathrm{PO}_{4}{ }^{3-}$ and $\mathrm{NH}_{4}{ }^{+}$ pulses in this study are likely influenced by fire-induced changes to soil chemistry and future studies should examine the homogeneity of $\mathrm{pH}$ buffering and nutrient pulses across the burned landscape.
\end{abstract}

Keywords: prescribed fire; nitrogen; phosphorous; water quality; forest management

\section{Introduction}

Prescribed fire is annually applied to nearly one million forested hectares in the Southeastern United States, where it is largely effective at accomplishing landscape scale management objectives [1,2]. Prescribed fire is a valuable tool for forest managers and is understood to benefit the long-term functions of many fire-adapted ecological communities [3,4]. Yet contemporary knowledge on the immediate effects of prescribed fire on nutrient cycling and sub-surface water quality in managed timber crop forests remains limited in the Southern Appalachian Mountains, where it is practiced extensively to meet productivity and forest health objectives $[1,5,6]$. Forested watersheds in the Southern Appalachians are important sources of clean water for rural and urban populations and are often managed to provide such services while, in many cases, still meeting timber crop productivity objectives $[2,7]$. Both human and natural disturbances can affect forest hydrology and water quality, and the environmental impact of these effects is driven by site-specific properties such as fuel type and quantity, topography, and 
seasonality [8]. Due to the powerful role of fire in shaping both terrestrial and aquatic communities in the Southern Appalachians, sub-surface macronutrient pools, such as nitrogen $(\mathrm{N})$ and phosphorous $(\mathrm{P})$, are a sensitive indicator of ecosystem response to disturbance $[9,10]$.

The application of prescribed fire has immediate effects on the biological, physical, and chemical properties of soil, particularly $\mathrm{pH}$, which affect the movement and concentrations of limiting macronutrients, primarily biologically available forms of nitrogen $(\mathrm{N})$ and phosphorous $(\mathrm{P})$ [11-13]. Typically, the combustion of woody debris or leafy organic matter results in the rapid loss of $\mathrm{N}$ and $\mathrm{P}$ containing biomass from the forest floor by means of volatilization, ash transportation, and/or mineralization [14-16]. However, biologically available forms of inorganic $\mathrm{N}$ or $\mathrm{P}$ may persist post-fire in the absence of plant re-uptake. Movement of excess quantities of these nutrients into perennial lakes or streams raises water quality concerns for both aquatic life and human health [2,17]. Additionally, loss of $\mathrm{N}$ from a system may impair post-fire recovery and can be indicative of diminished site productivity if substantial nutrient loss occurs [12,18]. Studies suggest that prescribed fire, which is often considered low-severity in terms of the amount of fuel consumed [19], has little long-term impact on forest nutrient pools and forested watershed resources [14]. Yet the processes that govern nutrient response after burning are still not clearly identified in Southern Appalachian forests [20].

Prescribed fire is used to maintain an open understory in southern yellow pine (Pinus virginiana Mill., P. pungens Lamb., P. echinata Mill., P. taeda L.) timber crop stands in the Southern Blue Ridge Mountains by the South Carolina Department of Natural Resources (SCDNR). The practice is largely effective at curtailing the growth of competitive woody species, primarily mountain laurel (Kalmia latifolia L.), red maple (Acer rubrum L.), and yellow poplar (Liriodendron tulipifera L.), as well as herbaceous species such as greenbrier (Smilax sp.) and blackberry (Rubus sp.). While measures are taken to mitigate the extent and intensity of the prescribed fire, contemporary knowledge is limited on the immediate impact of prescribed fire on water quality from watersheds in managed timber stands, as it is difficult to identify causal agents of excess nutrient exports $[18,20]$. It is important to assess the impact of prescribed fire on small forested watersheds due to the magnifying effect of high order streams on downstream water quality, and the typically low concentrations of macronutrients in undisturbed forested streams in the Southern Appalachian Mountains [15]. Regulating agencies have established concentration standards in surface waters to protect clean water from excess constituents such as biologically available $\mathrm{N}$ and $\mathrm{P}[2,20]$. Specifically, concentrations of inorganic $\mathrm{N}$ forms that exceed $10 \mathrm{mg} / \mathrm{L}$ [21] in water are considered unsafe for human consumption and aquatic organisms, though increases of this magnitude after fire are uncommon [2]. Inorganic $\mathrm{P}$ in lakes and streams is typically low [22,23] and contemporary studies suggest that burning increases the mobility of biologically available orthophosphate, which poses eutrophication risks in surface water [24,25].

The goal of this study was to quantify immediate sub-surface $\mathrm{N}$ and $\mathrm{P}$ response to prescribed fire to identify possible water quality or site productivity risks. To accomplish this, we initiated a five-month study monitoring available sub-surface inorganic $\mathrm{N}$ and $\mathrm{P}$ concentrations, specifically ammonium $\left(\mathrm{NH}_{4}{ }^{+}\right)$, nitrate $\left(\mathrm{NO}_{3}{ }^{-}\right)$, and orthophosphate $\left(\mathrm{PO}_{4}{ }^{3-}\right)$, as well as $\mathrm{pH}$. The specific objectives were to (1) quantify the immediate effect of prescribed fire on sub-surface concentrations of biologically available $\mathrm{NH}_{4}{ }^{+}, \mathrm{NO}_{3}{ }^{-}, \mathrm{PO}_{4}{ }^{3-}$, and $\mathrm{pH}$; (2) identify processes that contribute to observed effects on sub-surface nutrient pools to (3) determine if prescribed fire has the potential to negatively affect water quality or forest health through the leaching of key macronutrients.

\section{Materials and Methods}

\subsection{Site Description}

This study was conducted in cooperation with the SCDNR at Jocassee Gorges Management Area, located at the convergence of the Piedmont foothills and the lower Blue Ridge Escarpment in the upstate of South Carolina ( $\left.35^{\circ} 58^{\prime} 28^{\prime \prime} \mathrm{N}, 82^{\circ} 51^{\prime} 57^{\prime \prime} \mathrm{W}\right)$. The landscape contains sharp topographic contrasts as the foothills of the Piedmont rise nearly 600 vertical meters marking the rise of the Southern Blue 
Ridge Mountains. The topography is governed by steep gorges incised into the metamorphic parent material and slopes are covered by a mixed hardwood-conifer overstory. Dominant canopy species include southern yellow pines, white oak (Quercus alba L.), yellow poplar, and red maple. Loblolly pine plantations are also found in some lower elevation sites. Soils are Pacolet series ( $\mathrm{PaC} 2)$ histosols, characterized by a porous, fine sandy loam A horizon and a pronounced sandy clay B horizon [26]. Soils at the site were relatively acidic and had low total N (Table 1), which is characteristic of yellow pine forests [9,12]. Jocassee Gorges Management Area has an average annual rainfall of $2000 \mathrm{~mm}$ (Sunset, SC, National Climatic Database). Temperature and precipitation data were collected weekly at the field site. Weekly rainfall was collected in a generic all-weather rain gauge (Forestry Suppliers No. 88994) mounted to a post located in the center of the stand. The rain gauge was emptied after each visit. In weeks with multiple rain events, data was collected after each rain event and added to the weekly total rainfall. Weekly temperature was measured to the nearest degree with a digital thermometer built into the vehicle used to access the field site. The vehicle was parked for at least thirty minutes before taking the temperature reading. The study site had been previously burned in March 2015 and is scheduled for another prescribed fire in 2023 before the next thinning.

Table 1. Summary of mean reference soil $(\mathrm{n}=4)$ and litter $(\mathrm{n}=4) \mathrm{pH}$, total phosphorous (Total P) and Total Kjedahl Nitrogen (TKN) concentration in parts-per-million (ppm) collected from yellow pine forests in Jocassee Gorges Management area in February 2019 prior to prescribed fire application. Values in parentheses are standard deviation.

\begin{tabular}{cccc}
\hline Sample Type & $\mathbf{p H}$ & Total P $\mathbf{( k g} / \mathbf{h a})$ & TKN (ppm) \\
\hline Soil & $5.0(0)$ & $7.6(2.4)$ & $0.6(0.6)$ \\
Litter & $5.4(0.4)$ & $8.9(1.6)$ & $0.8(0.06)$ \\
\hline
\end{tabular}

\subsection{Study Design and Data Collection}

Fire crews from the SCDNR conducted a prescribed fire on March 9th, 2019 at Jocassee Gorges Management Area to clear understory woody vegetation and reduce fuel loads in yellow pine stands. Air temperature was approximately $7^{\circ} \mathrm{C}$ for the duration of the prescribed fire (approximately 0900 to $1500 \mathrm{~h}$ Eastern Standard Time). Fuel was primarily low-moisture pine needles and dormant understory woody vegetation. The fire was ignited in strips along the upper ridge using drip torches and allowed to burn into dry ephemeral stream beds.

Two 50-hectare yellow pine stands managed for timber production were selected for this study due to their schedule in the prescribed fire rotation. Both stands were on a slight slope (approximately $35^{\circ}$ ) in ephemeral drainages. Soil solution was collected at the intersection of the A and B soil horizons approximately $30 \mathrm{~cm}$ below the surface using $30 \mathrm{~cm}$ porous cup lysimeters (Hanna Instruments HI89300-30) that were installed in transects. Transects consisted of one lysimeter at the top of the hillslope and another lysimeter $30 \mathrm{~m}$ below towards the bottom of the slope. Five transects were installed in each stand with a spacing of approximately $100 \mathrm{~m}$ between transects. Each stand contained one designated control transect and four burn transects subject to the prescribed fire (Figure 1). A fire break was installed adjacent to control transects to prevent them from burning.

Prior to installation, lysimeters were sterilized and activated with Hanna Instruments HI83900-25 cleaning solution. In late February 2019, before the prescribed fire, lysimeters were installed in both stands and allowed to calibrate for one week. Litter and soil samples were also collected from both stands before burning and analyzed for baseline total Kjeldahl nitrogen (TKN), total phosphorous (Total P), and $\mathrm{pH}$. Reference soil and litter samples were analyzed at the Clemson University Agricultural Lab.

Soil solution samples were collected weekly starting in February 2019 (approximately two weeks before the prescribed fire) and continued through July 2019 (approximately 16 weeks post-fire). Soil solution samples were immediately analyzed for $\mathrm{pH}, \mathrm{NH}_{4}{ }^{+}, \mathrm{NO}_{3}{ }^{-}$, and $\mathrm{PO}_{4}{ }^{3-}$ concentrations using a FIAlab Flow Injection Analyzer-1000 (FIAlyzer) (FIAlab Instruments Inc., Seattle, WA, 
2018). Ammonium concentrations were measured using the Environmental Protection Agency (EPA) recommended FIA-012 gas diffusion and salicylate method. Nitrate concentrations were measured using the EPA compliant FIA-026 Cadmium reduction ASTM 4500-NO3-I method. Phosphate concentrations were measured using the EPA compliant FIA-073 automated ASTM 4500-P G-199 method [27]. Sample pH was measured using Hanna Instruments HI9814 probe (Hanna Instruments, USA, 1978-2020). Samples were stored in a freezer after analysis. Lack of solution for 12 lysimeter samples was attributed to low precipitation and soil water uptake by regenerating plants starting in May 2019.

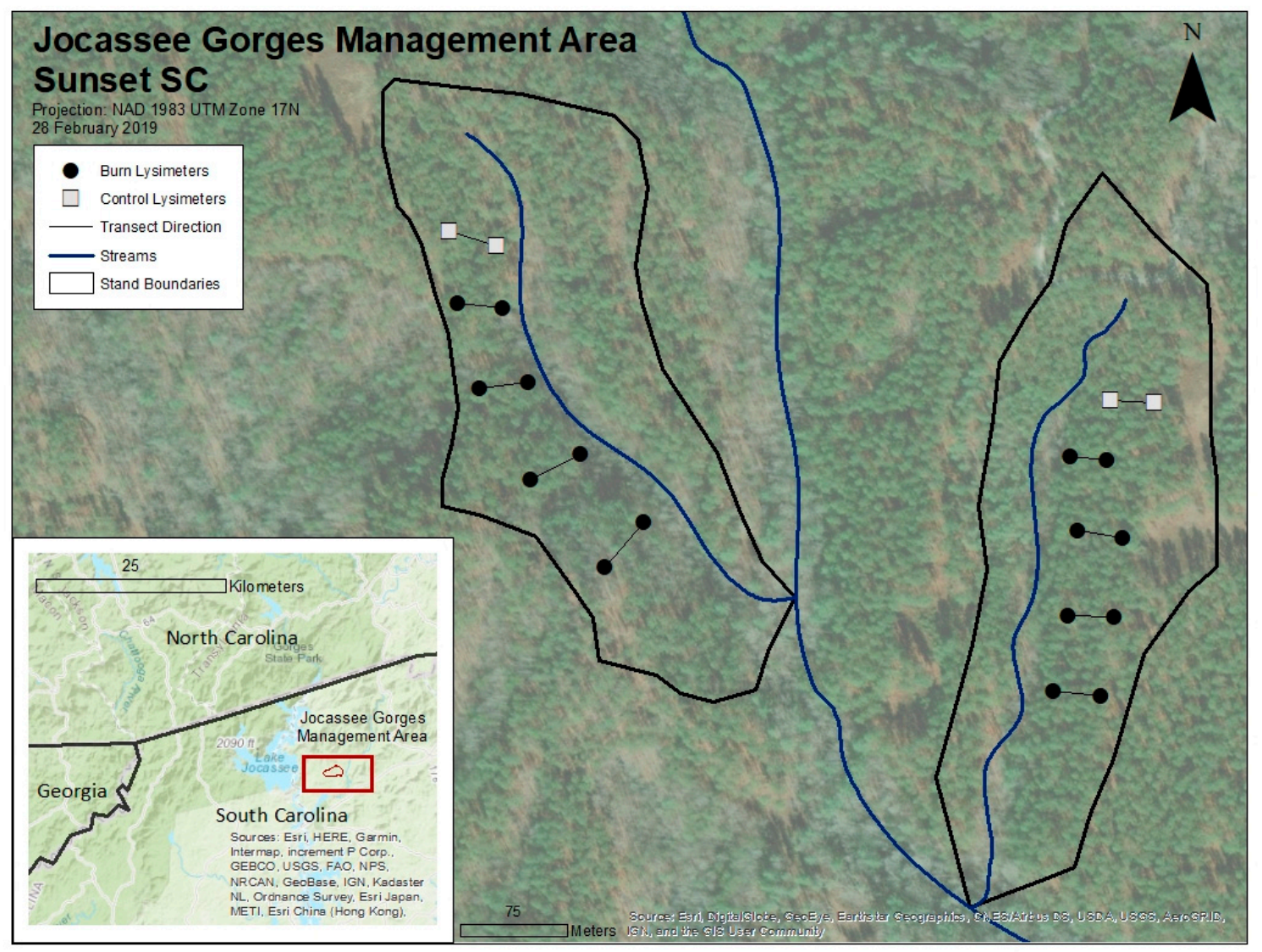

Figure 1. Map of pine stands and burn and control sampling transects in two yellow pine stands at Jocassee Gorges Management Area.

\subsection{Statistical Analyses}

We used a control-impact experimental design to compare nutrient concentrations and $\mathrm{pH}$ between control and burned transects. We used transects as the unit of analysis with each weekly transect value recorded as the average of two lysimeter sampling points. We examined the mean and maximum nutrient concentrations to compare control and burned transects across the five-month duration of the study. We used a means comparison t-test in JMP (JMP Pro, Version 14.1.0. SAS Institute Inc., Cary, NC, 1989-2020) to determine significant differences between control and burned transects using the average of the five-month sampling period for each transect by condition (Burn vs. Control). We conducted repeated measures analysis of variance (ANOVA) on pooled weekly values in JMP to determine mean concentration responses between control and burned transects during each sampling event. The dependent variable was nutrient concentration or $\mathrm{pH}$; the date of each sampling event and burn condition (burn vs. control) were the independent variables in the repeated measures ANOVA. Data fit all model assumptions. We used Tukey's honest significant difference (HSD) post-hoc test to determine differences between all possible combinations of burn and control transects. 


\section{Results}

The prescribed fire in this study resulted in low-severity burns, consistent with the management objective to reduce understory woody vegetation and fuel loads. The litter layer was partially consumed but the underlying duff layer experienced minimal charring. Litter was retained in gully bottoms and burning was minimal in other moist or shaded areas, which is characteristic of low severity fire [19]. Post-fire grass and herbaceous vegetation regeneration was rapid in burned sites at the onset of the growing season in May 2019. Mean weekly rainfall during the study period was $28.9 \mathrm{~mm}$. Temperatures ranged between $0{ }^{\circ} \mathrm{C}$ and $26^{\circ} \mathrm{C}$ during the study period from February to July (Figure 2). The prescribed fire increased the five-month maximum $\mathrm{NH}_{4}{ }^{+}, \mathrm{PO}_{4}{ }^{3-}$ relative to control. The five-month mean $\mathrm{pH}$ was greater in burned transects than the control (Table 2).

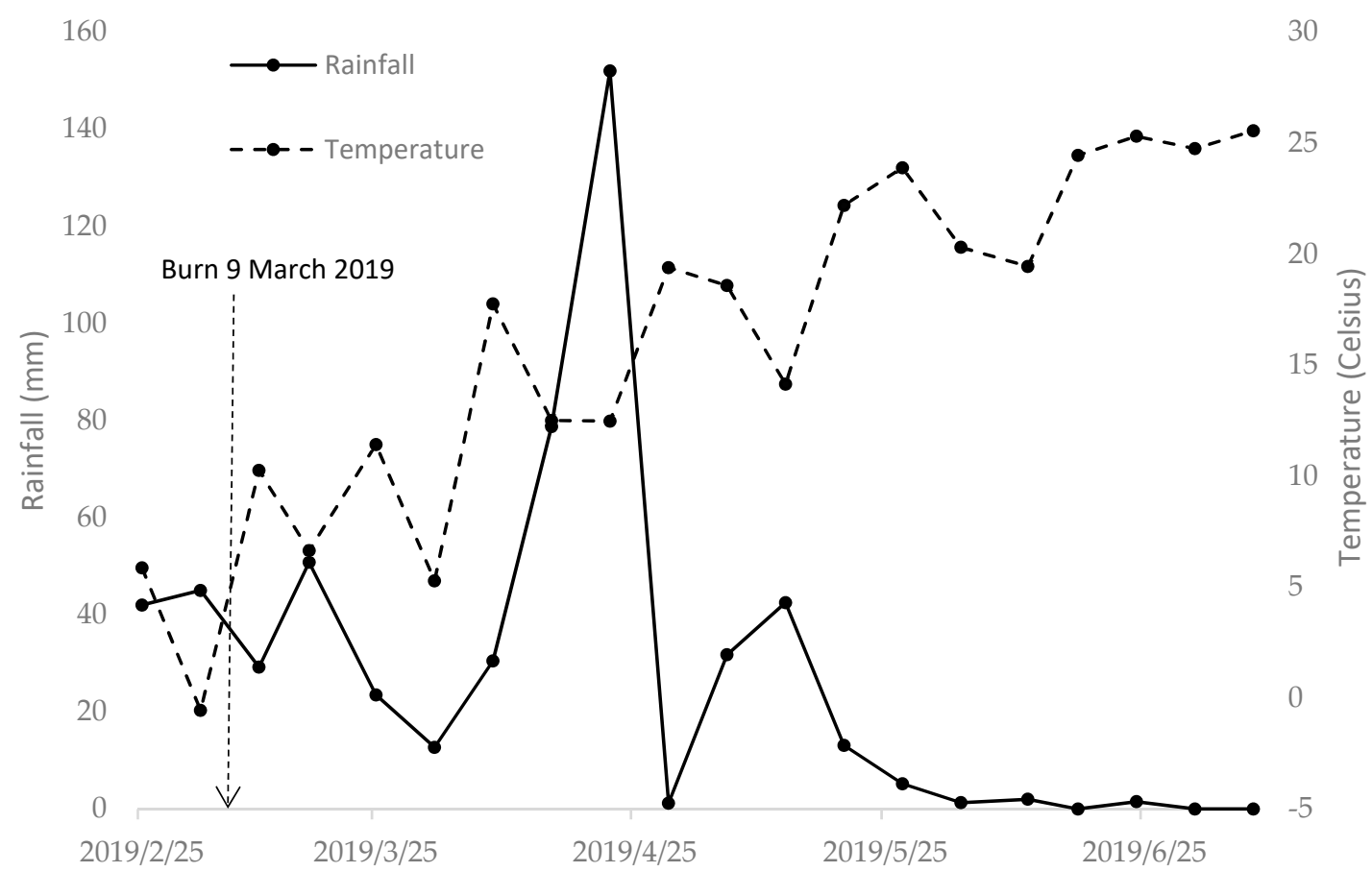

Figure 2. Weekly aggregate rainfall ( $\mathrm{mm}$ ) and temperature (Celsius) during each sampling event from February to July 2019 at Jocassee Gorges Management Area, Sunset, SC.

Table 2. Five-month mean parameters of soil solution variable nutrient concentrations $(\mathrm{mg} / \mathrm{L})$ and $\mathrm{pH}$ at $30 \mathrm{~cm}$ depth between burned and control stands in the Southern Blue Ridge mountains of upstate South Carolina. Burn values marked by an asterisk are significantly different from the control at the 0.05 significance level. Parenthetical values are standard deviation.

\begin{tabular}{cccccc}
\hline Parameter & Condition & $\mathbf{P O}_{4}{ }^{3-}$ & $\mathrm{NO}_{3}{ }^{-}$ & $\mathbf{N H}_{4}{ }^{+}$ & pH \\
\hline \multirow{2}{*}{ Maximum } & Control & $1.90(4.0)$ & $0.49(0.33)$ & $1.37(1.0)$ & $5.7(0.07)$ \\
& Burn & $6.57^{*}(0.2)$ & $0.65(0.36)$ & $18.02 *(11.03)$ & $6.1(0.3)$ \\
\hline \multirow{2}{*}{ Mean } & Control & $0.53(0.04)$ & $0.1(0.04)$ & $0.21(0.1)$ & $4.3(0.01)$ \\
& Burn & $1.55(1.43)$ & $0.15(0.07)$ & $2.48(2.2)$ & $4.9 *(0.01)$ \\
\hline
\end{tabular}

\section{1. $\mathrm{NO}_{3}{ }^{-}$}

$\mathrm{NO}_{3}{ }^{-}$concentrations were low throughout the entire sampling period, reaching a maximum concentration of $0.65( \pm 0.4) \mathrm{mg} / \mathrm{L}$. Additionally, there were no parameter differences between burned and control transects (Table 2). Gaps in recorded measurements (Figure 3) represent concentrations below the detection threshold of the FIAlyzer of $0.005 \mathrm{mg} / \mathrm{L}$. 


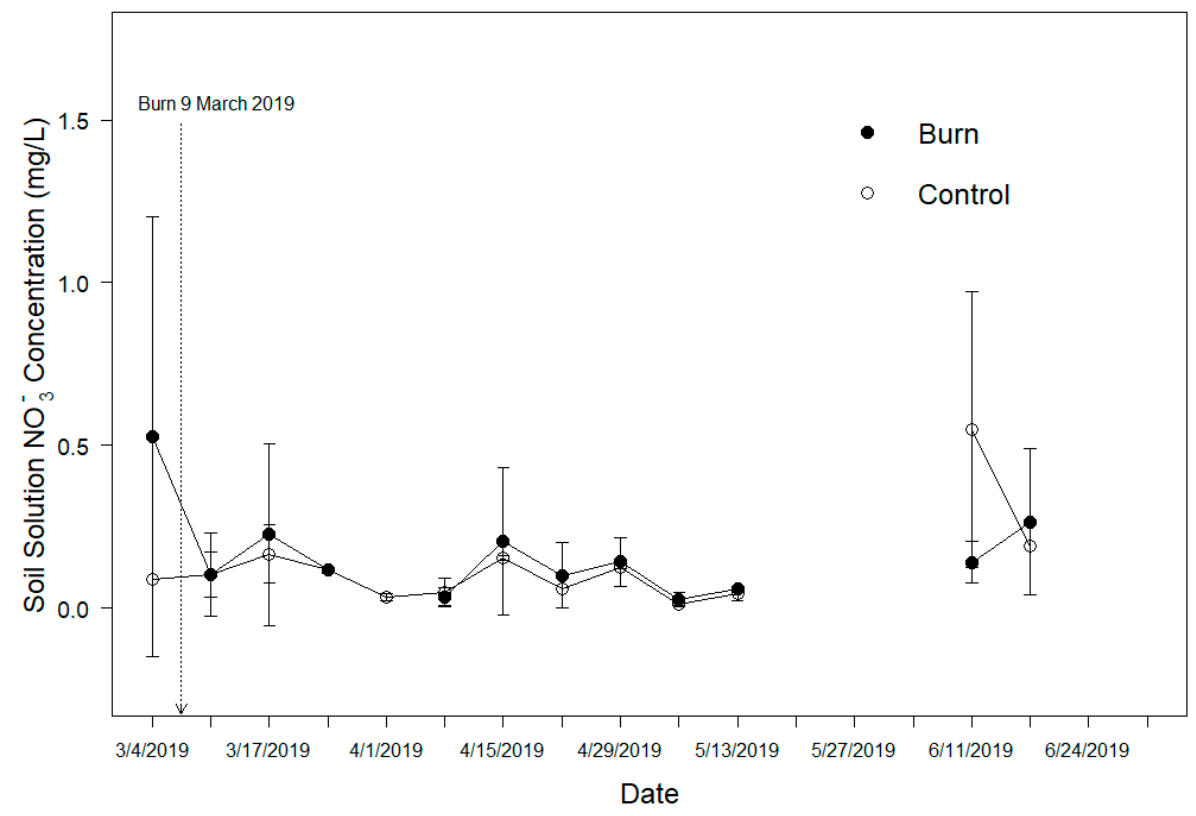

Figure 3. Soil solution $\mathrm{NO}_{3}{ }^{-}$concentrations (mg/L) sampled from Feb. 2019 to July 2019 in a yellow pine forest in the Southern Blue Ridge Mountains of South Carolina. Values are weekly means with standard error bars.

\section{2. $\mathrm{NH}_{4}^{+}$}

Soil solution $\mathrm{NH}_{4}{ }^{+}$experienced an observable pulse immediately following the prescribed fire; concentrations declined rapidly between the third and fourth week post-fire. The five-month maximum $\mathrm{NH}_{4}{ }^{+}$was 12 times greater in burn transects $(18.02 \pm 11.0 \mathrm{mg} / \mathrm{L})$ than control $(1.4 \pm 1.0 \mathrm{mg} / \mathrm{L})$ and this difference was significant $\left(t_{6.5}=3.61, p=0.009\right)$. Concentrations in burned transects decreased to that of control values $(<0.1 \mathrm{mg} / \mathrm{L})$ approximately three weeks post-fire (Figure 4$)$. There was no difference $\left(F_{1,14}=0.12, p=0.700\right)$ between pooled burned or control values during at any individual sampling event over the course of the study.

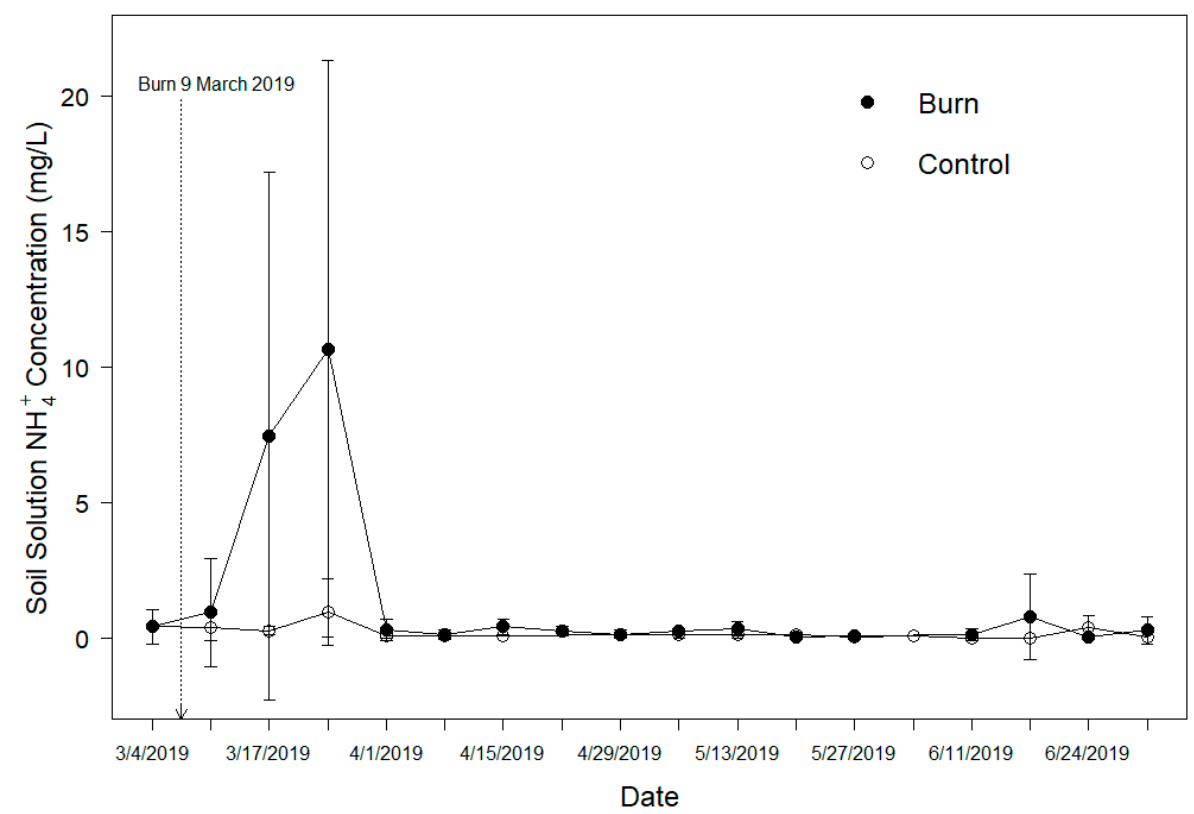

Figure 4. Soil solution $\mathrm{NH}_{4}{ }^{+}$concentrations (mg/L) sampled from February 2019 to July 2019 in a yellow pine forest in the Southern Blue Ridge Mountains of South Carolina. Values are weekly means with standard error bars. 


\section{3. $\mathrm{PO}_{4}{ }^{3-}$}

Phosphate concentrations increased in burn transects relative to control transects. The five-month maximum $\mathrm{PO}_{4}{ }^{3}$ concentration $(6.57 \pm 0.2 \mathrm{mg} / \mathrm{L})$ in burn transects was approximately three times greater than control $(1.9 \pm 4.0 \mathrm{mg} / \mathrm{L})$ and this difference was significant $\left(t_{6.2}=2.84, p=0.029\right)$. There was no difference $\left(F_{1,14}=0.74, p=0.400\right)$ between pooled weekly burn and control concentrations during any sampling event. Elevated $\mathrm{PO}_{4}{ }^{3-}$ concentrations $(>1.0 \mathrm{mg} / \mathrm{L})$ were measured for five weeks post-fire and did not experience a notable return to baseline concentrations until the final sampling event, contrasting the $\mathrm{NH}_{4}{ }^{+}$behavior, though there were low $(<0.1 \mathrm{mg} / \mathrm{L})$ concentrations recorded in burned samples throughout the sampling period (Figure 5).

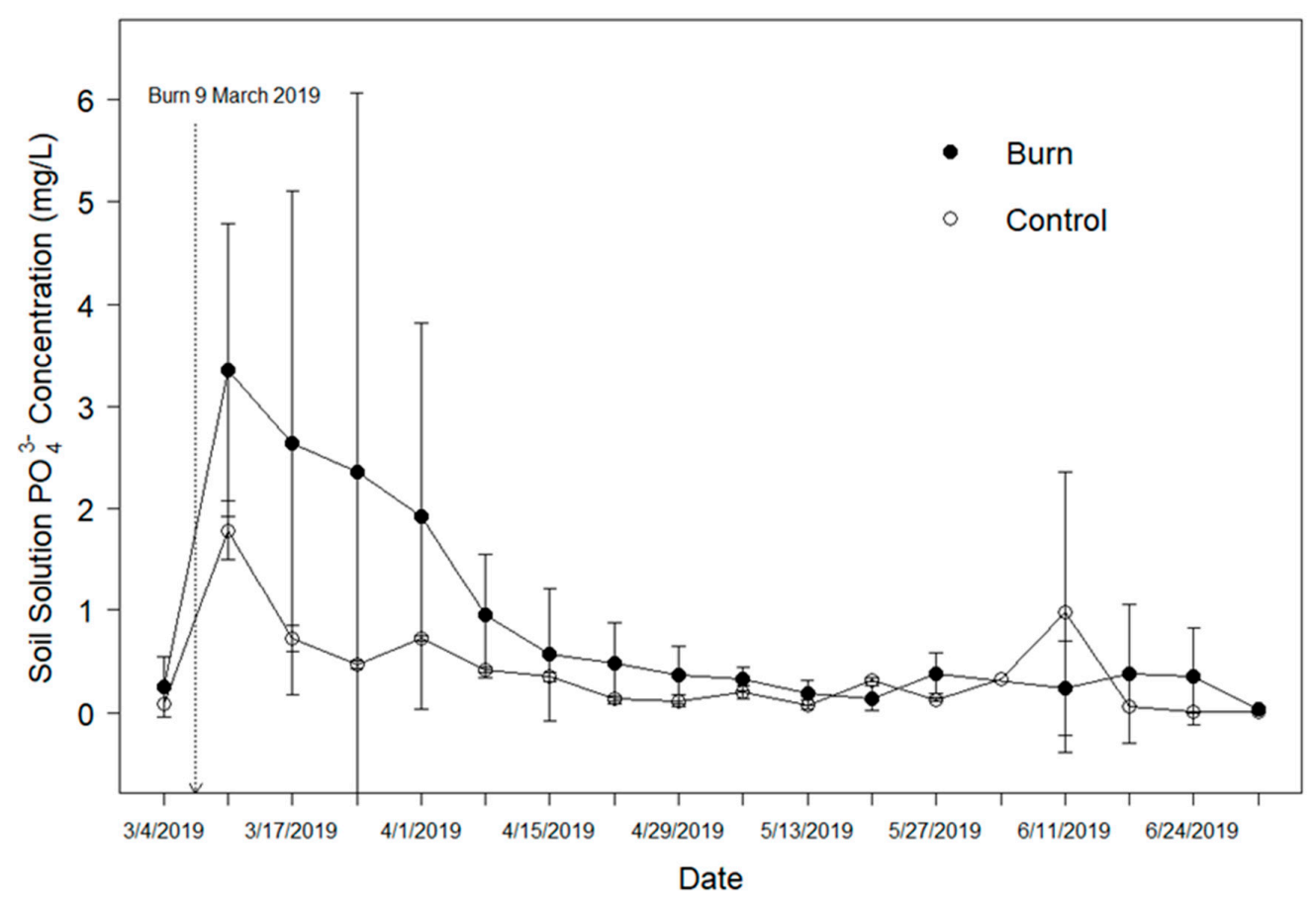

Figure 5. Soil solution $\mathrm{PO}_{4}{ }^{3-}$ concentrations (mg/L) sampled from February 2019 to July 2019 in a yellow pine forest in the Southern Blue Ridge Mountains of South Carolina. Values are weekly means with standard error bars.

\section{4. $p H$}

The mean five-month soil solution $\mathrm{pH}$ was significantly greater $\left(t_{5.6}=15.85, p<0.001\right)$ in burn $(4.9 \pm 0.01)$ than control $(4.3 \pm 0.01)$ transects. The average maximum $(6.1 \pm 0.3)$ in burned transects suggests some fire-induced $\mathrm{pH}$ buffering, though these parameters were not statistically different from the control (Table 2). There were no apparent increasing or decreasing trends in burn or control solution $\mathrm{pH}$ over the five-month sampling period, save generally lower $\mathrm{pH}$ in control transects (Figure 6). Five-month mean soil solution $\mathrm{pH}$ in both burn and control transects was representative of local soil $\mathrm{pH}$ indicating that, while mean $\mathrm{pH}$ was elevated in burn transects, prescribed fire induced $\mathrm{pH}$ buffering was limited and heterogeneous across the landscape. 


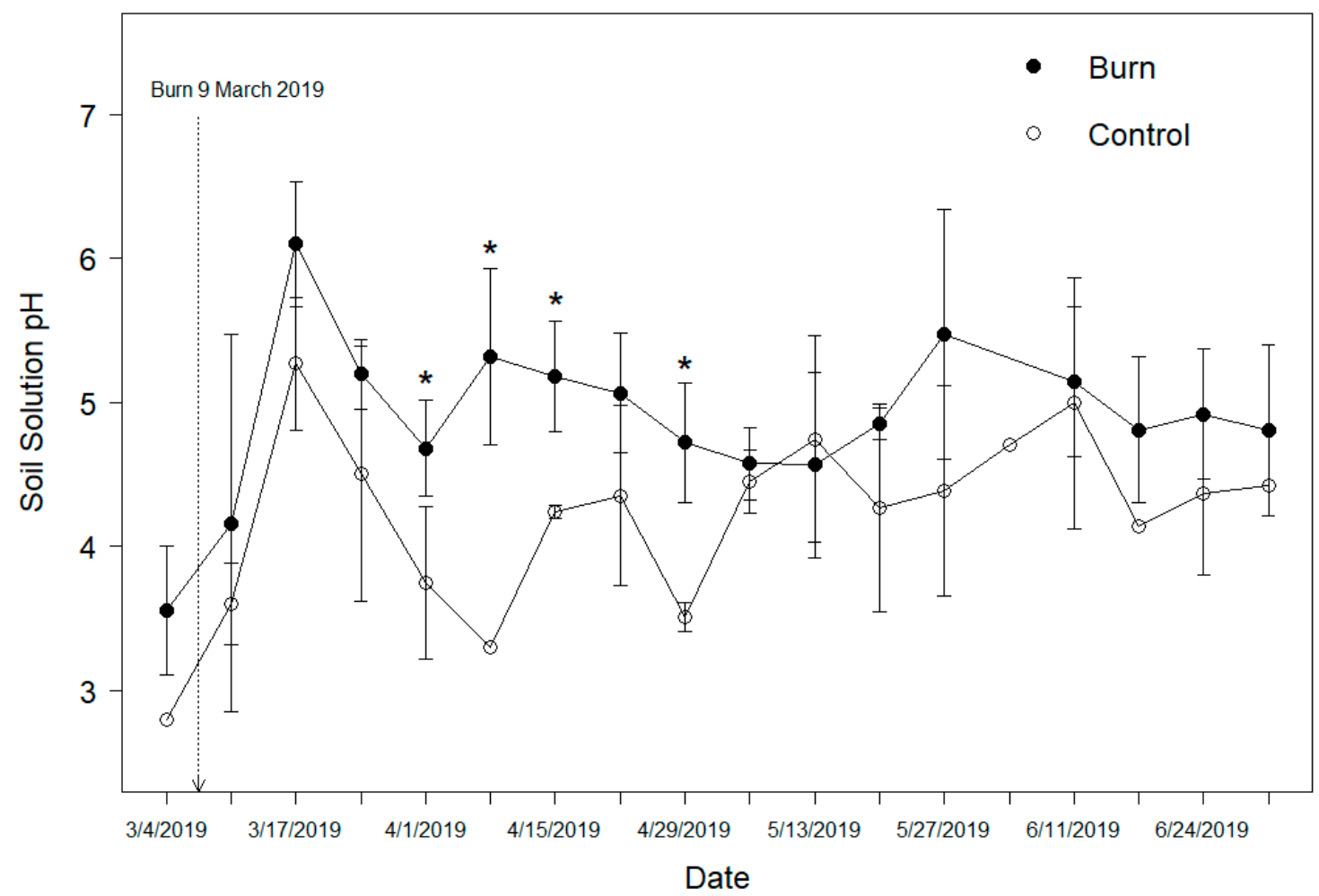

Figure 6. Soil solution pH sampled from March 2019 to July 2019 in a yellow pine forest in the Southern Blue Ridge Mountains of South Carolina. Values are weekly means with standard error bars. Weekly burn measurements denoted by an asterisk $\left(^{*}\right)$ are significantly greater than the control at the 0.05 significance level.

\section{Discussion}

The weekly sampling during this study captured a pulse of inorganic nutrients that may not have been observed at a less frequent sampling interval [20]. This study suggests that when prescribed fire is applied during the late dormant season, it causes a benign pulse of nutrients in an otherwise $\mathrm{N}$ limited ecosystem. Similar studies have examined nutrient response to prescribed fire in other terrestrial and aquatic environments and a pulse of nutrients is not uncommon, however it is difficult to isolate contributing factors to these pulses [20,28]. While a pulse of nutrients causes an immediate increase in biologically available nutrients, the prescribed fire in this instance likely reduced total nutrient pools [9]. The reduction of total nutrient pools is advantageous to the yellow pine overstory whereby acidic, $\mathrm{N}$ limited soils reduce the competitiveness of understory woody vegetation. While overall changes to nutrient pools were short-lived (elevated concentrations in burned transects persisted for only several weeks), changes to soil chemistry in burned transects may help explain the pulse of inorganic $\mathrm{N}$ and $\mathrm{P}$ observed in this study.

\subsection{Fire Effects on $\mathrm{NO}_{3}{ }^{-}$}

Increased terrestrial or subsurface $\mathrm{NO}_{3}{ }^{-}$concentrations after fire is unlikely because $\mathrm{NO}_{3}{ }^{-}$is volatilized at temperatures as low as $200{ }^{\circ} \mathrm{C}[3,29,30]$. In the present study, prescribed fire had little impact on sub-surface $\mathrm{NO}_{3}{ }^{-}$concentrations. However, post-fire $\mathrm{N}$ loss by volatilization or plant uptake may benefit forests by reducing total organic nutrient pools that have become $\mathrm{N}$-enriched in the absence of fire. Additionally, $\mathrm{N}$ response to fire is strongly associated with soil heating; low-severity fuel consumption, low soil heating, and low total $\mathrm{N}$ in both litter and soil are the primary factors explaining the lack $\mathrm{NO}_{3}{ }^{-}$response in this study $[12,15,30]$. Though $\mathrm{NO}_{3}{ }^{-}$concentrations were low $(<0.1 \mathrm{mg} / \mathrm{L})$ and at times below the detection threshold, they were representative of ambient concentrations in undisturbed, small forested watersheds of between $0.05-0.15 \mathrm{mg} / \mathrm{L}$ [31]. Weekly sampling in this study 
did not detect a pulse of $\mathrm{NO}_{3}{ }^{-}$during the same time period as $\mathrm{NH}_{4}{ }^{+}$or $\mathrm{PO}_{4}{ }^{3-}$; more frequent sampling (i.e., daily) pre and post-fire may be required to better understand $\mathrm{NO}_{3}{ }^{-}$response to prescribed fire.

\subsection{Fire Effects on $\mathrm{NH}_{4}^{+}$}

This study documented a pulse of $\mathrm{NH}_{4}{ }^{+}$immediately following the application of low-severity prescribed fire. The $\mathrm{NH}_{4}{ }^{+}$increase echoes similar studies' results that also reported increased $\mathrm{NH}_{4}{ }^{+}$ in stream water or soil solution after burning $[13,14,32]$. A likely explanation for this increase is that volatilized $\mathrm{N}$ contained in the ash layer leached downward, allowing $\mathrm{NH}_{4}{ }^{+}$to pool in the soil until it was either absorbed by plants, adsorbed to negatively charged clay particles or transformed into $\mathrm{NO}_{3}{ }^{-}[5,15,33]$. The decline of $\mathrm{NH}_{4}{ }^{+}$in burned transects to near control values $(<0.2 \mathrm{mg} / \mathrm{L})$ between the third and fourth week of sampling (25 March-1 April, 2019) suggests that rapid nitrification and mineralization of available $\mathrm{NH}_{4}{ }^{+}$occurred at the start of the growing season [11,34]. High clay content at the intersection of the $\mathrm{A} / \mathrm{B}$ soil horizon in southern Appalachian soils prevents $\mathrm{NH}_{4}{ }^{+}$leaching and elevated $\mathrm{NH}_{4}{ }^{+}$pools can function as a source for both plant uptake and conversion to $\mathrm{NO}_{3}{ }^{-}$. Understory herbaceous vegetation growth starting in early May 2019 likely played a key role in limiting the pulse of $\mathrm{NH}_{4}{ }^{+}$, as the prescribed fires conducted at the end of or during the growing season may result in an extended period of elevated nutrient pools in the absence of plant regeneration or microbial activity $[5,7,14,35]$. For example, Bêche et al. [24] recorded elevated $\mathrm{NH}_{4}{ }^{+}$in stream water for nearly 12-months after a prescribed fire conducted in October at the onset of the dormant season.

Though the five-month mean $\mathrm{NH}_{4}{ }^{+}$concentration of $2.48( \pm 2.2) \mathrm{mg} / \mathrm{L}$ from burned transects was not significantly different from control transects, it is greater than flow-weighted ambient concentrations in undisturbed Southeastern streams of approximately $0.05 \mathrm{mg} / \mathrm{L}$ [31]. While $\mathrm{NH}_{4}{ }^{+}$experienced a pulse following prescribed fire application, total $\mathrm{N}$ pools were likely depleted by means of volatilization or conversion to inorganic forms $[11,35]$. In an N-limited forest ecosystem, loss of organic $\mathrm{N}$ pools may initially reduce site productivity, yet from a restoration and water quality perspective, intermittent burning likely prevents sub-surface $\mathrm{N}$ saturation and subsequent movement into surface water. The drop of $\mathrm{NH}_{4}{ }^{+}$concentrations further suggests that the observed pulse was representative of an Assart effect or a pulse of nutrients after disturbance [36]. Regenerating herbaceous vegetation and grasses were likely responsible for the rapid decline in soil solution $\mathrm{NH}_{4}{ }^{+}$rather than yellow pines $[20,37]$. The prescribed fire, in this instance, likely confers an advantage to the fire-adapted yellow pine overstory whereby vegetation mortality and total $\mathrm{N}$ pool reduction limits the growth of competitive hardwood or shade tolerant species.

\subsection{Fire Effects on $\mathrm{PO}_{4}{ }^{3-}$}

While the P response to fire is well documented [22-24], few studies have examined the effects of prescribed fire on sub-surface or inorganic $\mathrm{P}$ in the Southern Blue Ridge Mountains and those that have, reported minimal response to burning $[5,31]$. This study documented a slight $\mathrm{PO}_{4}{ }^{3-}$ increase in soil solution after prescribed fire. The source of the $\mathrm{PO}_{4}{ }^{3-}$ increase in this study was likely existing organic $\mathrm{P}$ that became disassociated from soil metal ions as soil $\mathrm{pH}$ was buffered towards neutrality in burned transects. This represents perhaps the greatest concern for water quality associated with prescribed fire, as the five-month average concentration $(1.55 \pm 1.43 \mathrm{mg} / \mathrm{L})$ from burned transects was many times greater than $\mathrm{PO}_{4}{ }^{3-}$ concentrations in undisturbed southeastern streams of approximately $0.014 \mathrm{mg} / \mathrm{L}$ [31]. The gradual decline of $\mathrm{PO}_{4}{ }^{3-}$ concentrations in burned transects coincides with soil $\mathrm{pH}$ decline (Figure 6), making complexion onto soil metal cations (i.e. aluminum) and re-incorporation into organic sub-surface pools a likely sink. While prescribed fire caused a pulse of $\mathrm{PO}_{4}{ }^{3-}, \mathrm{P}$ loss and leaching was minimal due to low precipitation, soil water uptake from plant regeneration and complexion to metal cations as soil $\mathrm{pH}$ fluctuated. Elevated $\mathrm{PO}_{4}{ }^{3-}(>1 \mathrm{mg} / \mathrm{L})$ in burned transects likely persisted due to slower plant absorption, as $\mathrm{PO}_{4}{ }^{3-}$ is not as biologically mobile as $\mathrm{N}[11,14,22]$. While the elevated $\mathrm{PO}_{4}{ }^{3-}$ in this study poses little water quality risk, it highlights the role of soil chemistry in limiting nutrient saturation. 


\section{Conclusions}

This study offered detailed insight into the immediate responses of sub-surface nutrient pools in a managed yellow pine forest to low-severity prescribed fire. It is the conclusion of this study that the nutrient responses are indicative of healthy forest nutrient cycling processes and that fire-induced increases in nutrients are unlikely to impact forested watershed resources. The prescribed fire appears to have had no effect on soil solution $\mathrm{NO}_{3}{ }^{-}$. We hypothesize that this is because $\mathrm{NO}_{3}{ }^{-}$is highly mobile and requires low volatilization energy. The $\mathrm{N}$ behavior observed in this study suggests that fire is beneficial to the yellow pine overstory by reducing competitive woody vegetation and total nutrient pools. The notable pulse of $\mathrm{NH}_{4}{ }^{+}$was likely caused by inorganic $\mathrm{N}$ accumulation in the absence of plant ground water uptake and likely plays a role in patterns of plant species regeneration and distribution. It was inferred that $\mathrm{NH}_{4}{ }^{+}$uptake by regenerating vegetation represents a reduction of total $\mathrm{N}$ from the ecosystem. Slight $\mathrm{pH}$ buffering in burned transects may have played a role in elevated $\mathrm{PO}_{4}{ }^{3-}$ concentrations, but it is unlikely that the observed $\mathrm{PO}_{4}{ }^{3-}$ response to prescribed fire will impact watershed resources due to functionally inhibited leaching in acidic soils, although further research would be required to corroborate this. The generally acidic $\mathrm{pH}$ across the site may confer a $\mathrm{PO}_{4}{ }^{3-}$ sink due to the tendency of $\mathrm{PO}_{4}{ }^{3-}$ to bind to soil metal cations at low $\mathrm{pH}$. This study suggests that fire-induced $\mathrm{pH}$ buffering and a lack of plant water and nutrient uptake contributed to a pulse of sub-surface inorganic $\mathrm{N}$ and $\mathrm{P}$. Future studies should examine the homogeneity of $\mathrm{pH}$ buffering across the burned landscape as fire effects on soil chemistry likely play an important role in the spatial distribution of nutrient pulses.

Author Contributions: Conceptualization, P.H. and D.H.; methodology, D.H., D.P., P.H., and K.K.; software, K.K.; validation, D.H., D.P., and D.P.; formal analysis, K.K.; investigation, K.K.; resources, P.H.; data curation, K.K.; writing-original draft preparation, K.K.; writing—review and editing, D.H., D.P., and P.H.; visualization, P.H.; supervision, D.H., D.P., and P.H.; project administration, P.H.; funding acquisition, P.H. All authors have read and agreed to the published version of the manuscript.

Funding: This research received no external funding.

Conflicts of Interest: The authors declare no conflict of interest.

\section{References}

1. Melvin, M.A. Prescribed Fire Use Survey Report. In National Prescribed Fire Use Survey Report; Coalition of Prescribed Fire Councils Inc.: Asheville, NC, USA, 2018.

2. Hallema, D.W.; Sun, G.; Caldwell, P.V.; Norman, S.P.; Cohen, E.C.; Liu, Y.; Bladon, K.D.; McNulty, S.G. Burned forests impact water supplies. Nat. Commun. 2018, 9, 1-8. [CrossRef] [PubMed]

3. Certini, G. Effects of fire on properties of forest soils: A review. Oecologia 2005, 143, 1-10. [CrossRef] [PubMed]

4. Nowacki, G.J.; Abrams, M.D. The Demise of Fire and "Mesophication" of Forests in the Eastern United States. Bioscience 2008, 58, 123-138. [CrossRef]

5. Elliott, K.J.; Vose, J.M. Initial Effects of Prescribed Fire on Quality of Soil Solution and Streamwater in the Southern Appalachian Mountains. South. J. Appl. For. 2005, 29, 5-15. [CrossRef]

6. Van Lear, D.H.; Waldrop, T.A. History, Uses, and Effects of Fire in the Appalachians; US Department of Agriculture: Asheville, NC, USA, 1989; p. 20.

7. Grace, J.M.I. Forest Operations and Water Quality in the South. Am. Soc. Agric. Eng. 2005, 48, 871-880. [CrossRef]

8. Cawson, J.G.; Sheridan, G.J.; Smith, H.G.; Lane, P.N.J. Surface runoff and erosion after prescribed burning and the effect of different fire regimes in forests and shrublands: A review. Int. J. Wildl. Fire 2012, 21, 857-872. [CrossRef]

9. Wan, S.; Hui, D.; Luo, Y. Fire effects on nitrogen pools and dynamics in terrestrial ecosystems: A meta-analysis. Ecol. Appl. 2001, 11, 1349-1365. [CrossRef] 
10. Swift, L.W., Jr.; Elliott, K.; Ottmar, R.D.; Vihnanek, R.E. Site preparation burning to improve southern Appalachian pine - hardwood stands: Fire characteristics and soil erosion, moisture, and temperature. Can. J. For. Res. 1993, 23, 2242-2254. [CrossRef]

11. Fenn, M.E.; Poth, M.A.; Aber, J.D.; Baron, J.S.; Bormann, B.T.; Johnson, D.W.; Lemly, A.D.; McNulty, S.G.; Ryan, D.F.; Stottlemyer, R. Nitrogen Excess in North American Ecosystems: Predisposing Factors, Ecosystem Responses, and Management Strategies. Ecol. Appl. 2014, 8, 706-733. [CrossRef]

12. Richter, D.D.; Ralston, C.W.; Harms, W.R. Prescribed fire: Effects on water quality and forest nutrient cycling. Science 1982, 215, 661-663. [CrossRef]

13. Schoch, P.; Binkley, D. Prescribed burning increased nitrogen availability in a mature loblolly pine stand. For. Ecol. Manag. 1986, 14, 13-22. [CrossRef]

14. Knoepp, J.D.; Elliott, K.J.; Clinton, B.D.; Vose, J.M. Effects of prescribed fire in mixed oak forests of the southern Appalachians: Forest floor, soil, and soil solution nitrogen responses. J. Torrey Bot. Soc. 2009, 136, 380-391. [CrossRef]

15. Knoepp, J.D.; Swank, W.T. Site prepartion burning to improve souther Appalachian pine-hardwood stands: Nitrogen responses in soil, soil water and streams. J. For. Restor. 1993, 23, 2263-2270.

16. Liechty, H.O.; Hooper, J.J. Long-term effect of periodic fire on nutrient pools and soil chemistry in loblolly-shortleaf pine stands managed with single-tree selection. For. Ecol. Manag. 2016, 380, 252-260. [CrossRef]

17. Son, J.; Kim, S.; Carlson, K.H. Effects of Wildfire on River Water Quality and Riverbed Sediment Phosphorus. Water Air Soil Pollut. 2015, 226, 26. [CrossRef]

18. Djodjic, F.; Bo, K.; Bergstro, L. Phosphorus Leaching in Relation to Soil Type and Soil Phosphorus Content. J. Environ. Qual. Abstr. 2004, 684, 678-684. [CrossRef] [PubMed]

19. Keeley, J.E. Fire intensity, fire severity and burn severity: A brief review and suggested usage. Int. J. Wildl. Fire 2009, 18, 116-126. [CrossRef]

20. Ficken, C.D.; Wright, J.P. Contributions of microbial activity and ash deposition to post-fire nitrogen availability in a pine savanna. Biogeosciences 2017, 14, 241-255. [CrossRef]

21. EPA. Aqautic Life Ambient Water Quality Criteria for Ammonia-Freshwater 2013; EPA: Washington, DC, USA, 2013.

22. Ice, G.; Binkley, D. Forest Streamwater Concentrations of Nitrogen and Phosphorus. J. For. 2003, 101, 21-28.

23. Binkley, D. Patterns and Processes of Variation in Nitrogen and Phosphorus Concentrations in Forested Streams; NCASI: Raleigh, NC, USA, 2001.

24. Bêche, L.A.; Stephens, S.L.; Resh, V.H. Effects of prescribed fire on a Sierra Nevada (California, USA) stream and its riparian zone. For. Ecol. Manag. 2005, 218, 37-59. [CrossRef]

25. Neary, D.G.; Ryan, K.C.; DeBano, L.F. Wildland Fire in Ecosystems, effects of fire on soil and water. USDA-FS Gen. Tech. Rep. 2005, 4, 250.

26. United States Department of Agriculture. Soil Survey of Pickens County, South Carolina; United States Department of Agriculture: Washington, DC, USA, 1972.

27. US EPA. Analytical Methods Approved for Drinking Water Compliance Monitoring of Inorganic Contaminants and Other Inorganic Constituents. Water 2019, 2, 1-56.

28. Battle, J.; Golladay, S.W. Prescribed Fire's Impact on Water Quality of Depressional Wetlands in Southwestern Georgia. Am. Midl. Nat. 2003, 150, 15-25. [CrossRef]

29. Elliott, K.J.; Vose, J.M. Fire Effects on Water Quality: A Synthesis of Response Regulating Factors Among Contrasting Ecosystems. In Proceedings of the Second Interagency Conference on Research in the Watersheds, Otto, NC, USA, 16-18 May 2006.

30. Douglass, J.E.; Van Lear, D. Prescribed Burning and Water Quality of Ephemeral Streams in the Piedmont of South Carolina. For. Sci. 1983, 29, 181-189.

31. Binkley, D.; Ice, G.G.; Kaye, J.; Williams, C.A. Nitrogen and phosphorus concentrations in forest streams of the United States. J. Am. Water Resour. Assoc. 2004, 40, 1277-1291. [CrossRef]

32. Clinton, B.D.; Vose, J.M.; Knoepp, J.D.; Elliott, K.J. Stream Nitrate Response to Different Burning Treatment in Southern Appalachian Forests. In Proceedings of Fire Conference 2000: The First National Congress on Fire Ecology, Prevention, and Management; Tall Timbers Research Station: Tallahassee, FL, USA, 2003.

33. Debano, L.F. The role of fire and soil heating on water repellency in wildland environments: A review. J. Hydrol. 2000, 232, 195-206. [CrossRef] 
34. Weil, R.; Brady, N. The Nature and Properties of Soils, 15th ed.; Prentice Hall: Upper Saddle River, NJ, USA, 2017.

35. Vose, J.M.; Laseter, S.H.; Sun, G.; Mcnulty, S.G. Stream Nitrogen Response to Fire in the Southeastern U.S. In Proceedings of the 3rd International Nitrogen Conference, Contributed Papers, Nanjing, China, 12-16 October 2004.

36. Hahn, G.; Coates, T.A.; Latham, R.E. Prescribed fire effects on water quality and freshwater ecosystems in moist- temperate eastern North America. Nat. Areas J. 2018, 39, 46-57. [CrossRef]

37. Brockway, D.G.; Lewis, C.E. Long-term effects of dormant-season prescribed fire on plant community diversity, structure and productivity in a longleaf pine wiregrass ecosystem. For. Ecol. Manag. 1997, 96, 167-183. [CrossRef]

(C) 2020 by the authors. Licensee MDPI, Basel, Switzerland. This article is an open access article distributed under the terms and conditions of the Creative Commons Attribution (CC BY) license (http://creativecommons.org/licenses/by/4.0/). 